\title{
HAEMATOLOGICAL AND BIOCHEMICAL STUDIES ON JUSTICIA CARNEA LEAVES EXTRACT IN PHENYLHYDRAZINE INDUCED-ANEMIA IN ALBINO RATS
}

\author{
Chimaraoke Onyeabo ${ }^{1}$, Ngozi K. Achi ${ }^{1}$, Chima A. Ekeleme-Egedigwe ${ }^{2 \bowtie}$, \\ Chidinma U. Ebere ${ }^{1}$, Chidinma K. Okoro ${ }^{1}$ \\ ${ }^{1}$ Department of Biochemistry, College of Natural Sciences, Michael Okpara University of Agriculture \\ Umudike, PMB 7267, Umuahia, Abia State, Nigeria \\ 2Department of Chemistry/Biochemistry, Federal University Ndufu-Alike Ikwo \\ PMB 1010 Abakaliki, Ebonyi State, Nigeria
}

\begin{abstract}
Background. Justicia carnea is a medicinal plant used widely in Nigeria which is reported to have diverse functions, including blood-boosting potential.

Aim. The effect of the ethanol extract of Justicea carnea (JC) leaves in phenylhydrazine induced-anemia albino rats on haematological and lipid profile parameters was investigated.

Methods. The experimental animals were randomly grouped into five groups of six rats each - group 1 (non-anemic control), group 2 (anemic control), group 3 (500 mg/kg of JC extract), group 4 (1000 mg/ $\mathrm{kg}$ of JC extract) and group 5 (DMSO control). Phenylhydrazine was administered once at a dose of $80 \mathrm{mg} / \mathrm{kg}$ b.w. to induce hemolytic anemia. After 28 days of extract administration, they were humanely sacrificed and the serum collected was used for biochemical analysis.

Results. In the acute toxicity study, the $\mathrm{LD}_{50}$ was found to be above $5000 \mathrm{mg} / \mathrm{kg}$ body weight. Packed Cell Volume (PCV) values, Red Blood cell (RBC) and haemoglobin $(\mathrm{Hb})$ concentrations decreased $(p<0.05)$ significantly after 48 hours of phenylhydrazine induction, but after 28 days of administering extracts of Justicia carnea, PCV values, RBC and $\mathrm{Hb}$ increased $(p<0.05)$ significantly. There were significant $(p<0.05)$ decreases in cholesterol, triacylglycerol, and LDL cholesterol concentrations in the extract-administered groups (groups 3\&4) relative to the anemic control. There was a significant $(p<0.05)$ increase in HDL-cholesterol concentrations in the extract groups $(3 \& 4)$ relative to the non-anemic control.

Conclusion. Extracts of Justicia carnea not only reversed anemic conditions in the phenylhydrazine-induced rats, it also improved the lipid profile, and this may be attributed to its rich phytochemical, nutrient and vitamin composition. Therefore, the findings of the study suggest that $J$. carnea leaves could be used to manage lipid abnormalities associated with anemia.
\end{abstract}

Keywords: Justicia carnea, lethal dose, anemia, lipid profile, albino rats

Abbreviations: JC - Justicia carnea, LDL-C - Low Density Lipoprotein Cholesterol, HDL-C - High Density Lipoprotein Cholesterol, VLDL-C - Very Low Density Lipoprotein Cholesterol, b.w. - body weight, $\mathrm{LD}_{50}$ - Lethal Dose ${ }_{50}, \mathrm{PCV}-$ Packed Cell Volume. 


\section{INTRODUCTION}

Anemia is a serious global public health problem associated with an increased risk of morbidity and mortality especially in developing countries in Africa such as Nigeria. In poorer malaria-endemic countries, anemia is one of the commonest preventable causes of death in children under 5 years and in pregnant women (WHO, 2006) and thereby poses a great threat to global healthcare (Ashour, 2014). This disease is characterized by the decrease of the hemoglobin rate to less than $13 \mathrm{~g} / \mathrm{dl}$ in males or $12 \mathrm{~g} / \mathrm{dl}$ in females (Kanfer and Nicol, 1997). Anemia can be defined as a decrease in the ability of the blood to carry oxygen due to a decrease in the total number of erythrocytes (each having a normal quantity of hemoglobin), a diminished concentration of hemoglobin per erythrocyte, or a combination of both (Bull and Breton-Gorius, 1995).

Medicinal plants have been documented as having beneficial properties used for the management of various ailments because they have been discovered to contain bioactive compounds called phytochemicals (Fasuyi, 2006) and secondary metabolites that can protect humans against diseases (Kumar et al., 2009). Examples of some documented plants and fruits used in the treatment of anemic conditions are Cocos nuciferia (Benin Republic) (Tchogou et al., 2016), leaves extracts of Tectona grandis (Togo) (Diallo et al., 2008) and Justicia secunda Vahl in Benin (Gbenou et al., 2006). The availability of synthetic drugs used in the treatment of a specific disease is common but because of the high cost and side effects associated with their use (Chattopadhyay and Bandyopadhyay, 2005; Oze et al., 2008), attention is currently being focused on the use of medicinal plant products in the prevention or management of various diseases or ailments.

The genus Justicia, named after the $18^{\text {th }}$-century Scottish botanist James Justice, belongs to the large family of Acanthaceae consisting of about 600 species of herbs and shrubs native to the tropics and subtropics (Corrêa and Alcântara, 2012; Durkee, 1986). J. carnea (Justicia carnea) is a flowering plant, widely distributed in various parts of Africa. In Nigeria, the shrubs of $J$. carnea are grown around homesteads and act as fences, which are easy to grow and propagate from stem cuttings by pushing the stems 1 to 2 inches into the soil (Mabberley, 1997). A survey among the Igbo local populace in Nigeria revealed that the plant under study is locally called "ogwu obara" meaning blood tonic. The deep purple colored juice from the leaves of this plant is extracted either by soaking or boiling in water, which can be drunk as tea. In other localities in Nigeria, the raw leaves are chewed and used together with "nchu anwu" as culinary vegetables to garnish yam porridge.

Traditionally, several species of Justicia are used in the management of inflammation, gastrointestinal disorders, respiratory tract infection, fever, pain, diabetes, diarrhea, liver diseases, rheumatism and arthritis (Badami et al., 2003; Corrêa and Alcântara, 2012). They also possess anti-inflammatory, anti-allergic, anti-tumoral, anti-viral and analgesic activities (Radhika et al., 2013). Species of Justicia found in India, such as Justicia traquebareinsis and Justicia wynaadensis, have been reported to possess cardioprotective properties (Radhika et al., 2013) and antioxidant activity, respectively (Medapa et al., 2011). There is no documented scientific and experimental evidence on the use of Justicea carnea leaves in the modulation of lipid profiles in experimental animals. Therefore, the study was designed to ascertain both its haematological and lipid profile status in anemic rats treated with $J$. carnea leaves. This study will aid to establish whether individuals using these leaves as blood/tea tonic could also benefit from its lipid modulatory effect.

\section{MATERIALS AND METHODS}

\section{Plant materials}

Fresh leaves of $J$. carnea were collected from Amaba in the Isuikwuato Local Government Area of Abia state and were authenticated in the Forestry Department, at the College of Natural Resource Management, Michael Okpara University of Agriculture, Umudike, Abia State. The leaves were removed from the stems, sorted, washed and pulverized to powder using an electric blender after air drying. The powdered leaves were stored in airtight containers until use. Extraction was performed by dissolving $1 \mathrm{~kg}$ of a powdered sample of its leaves in $6 \mathrm{~L}$ of ethanol and allowing them to stand for 48 hours with constant stirring. At the end of the extraction, the solution was filtered using Whatman No. 1 filter paper, and the extract was concentrated to a semi-solid residue in a water bath at $60^{\circ} \mathrm{C}$ for 2 days. A total amount of $26.3 \mathrm{~g}$ of the extract was obtained. 


\section{Proximate analysis}

The parameters determined include ash, moisture, crude protein, fat, fiber and carbohydrate. All of these were carried out using the method of analysis described by (AOAC, 1990). The carbohydrate content was estimated as the difference of all other nutrients as follows:

$$
\begin{gathered}
\% \text { carbohydrate }=100-(\% \text { crude protein }+\% \text { crude } \\
\text { fiber }+\% \text { ash }+\% \text { lipid }+\% \text { moisture })
\end{gathered}
$$

\section{Phytochemical analysis}

Some of the phytochemicals investigated in the leaves include phenols, saponins, steroid, flavonoids, alkaloids and tannins using standard procedures (Harborne, 1998).

\section{Animal handling and grouping}

A total of 30 male albino rats weighing 90-116 g were used for the biochemical evaluation studies and 18 albino mice weighing 16.9-26.8 $\mathrm{g}$ were used for the acute toxicity $\left(\mathrm{LD}_{50}\right)$ study. All the experimental animals used were purchased from the Department of Veterinary Science, University of Nigeria, Nsukka. The animals were housed in standard polypropylene cages and were acclimatized for a week in the animal house of the Department of Biochemistry, College of Natural Sciences, Michael Okpara University of Agriculture, Umudike. The animals were allowed free access to food and water ad libitum. After acclimatization, they were randomly grouped into five groups of six animals. The animals for the study were handled following the approval by the Board of the Department of Biochemistry, which was in line with the National Institute of Health's guidelines for the care and use of Laboratory animals (NIH, 1978, publ. no. 8023; NRC, 1985).

Grouping was done as follows:

- group 1: non-anemic control

- group 2: anemic control

- group 3: anemic + extract (500 $\mathrm{mg} / \mathrm{kg}$ body weight)

- group 4: anemic + extract $(1000 \mathrm{mg} / \mathrm{kg}$ body weight)

- group 5: DMSO (dimethyl sulfoxide) control.

\section{Haematological analysis}

The haemoglobin $(\mathrm{Hb})$ concentration was estimated using the cyanomethaemoglobin photometric method.
The PCV was estimated using the micro-haematocrit centrifuge as described by Ochei and Kolhatkar (2008). The red blood cell (RBC) and white blood cell (WBC) count was estimated using an improved Neubauer haemocytometer. Eighteen male albino rats (groups 2, $3 \& 4$ ) received a single dose of freshly prepared phenyl hydrazine at a dose of $80 \mathrm{mg} / \mathrm{kg}$ body weight via intra-peritoneal route (I.P) after an overnight fast. The albino rats were kept and observed in their cages for $48 \mathrm{hrs}$. During this period the rats were fed ad libitum with Vital grower's mash and clean tap water. After $48 \mathrm{hrs}$, packed cell volumes (PCV) were determined using the procedure described by Ochei and Kolhatkar (2008) and the rats with a PCV lower than 50\% were considered anemic and suitable for the study. Extracts of this plant were administered orally to the animals with the aid of a gavage for 28 days. The stock of the extract prepared with $2 \%$ dimethyl sulfoxide (DMSO) was administered according to the body weight of the animals, which were weighed weekly. Since DMSO was used for the stock extract preparation, it serves as a control, which was allotted as group 5 .

\section{Acute toxicity studies}

Lethal doses $\left(\mathrm{LD}_{50}\right)$ were determined on nine mice using the proposed new Lorke method (1983). During the course of the experiment, the animals were observed for changes in physical characteristics and activity. In the initial phase, four animals were used. These animals were divided into four groups of one animal each. The different doses $(100 \mathrm{mg} / \mathrm{kg}, 300 \mathrm{mg} / \mathrm{kg}$, $500 \mathrm{mg} / \mathrm{kg}$ and $800 \mathrm{mg} / \mathrm{kg}$ ) of the extract of J. carnea were administered to the different animals. The second phase involved three animals, which were divided into three groups of one animal each. Different doses $(1000 \mathrm{mg} / \mathrm{kg}, 1500 \mathrm{mg} / \mathrm{kg}$ and $2000 \mathrm{mg} / \mathrm{kg})$ of the extract were administered to the various animals and then observed for 1 hour after administration and periodically for 24 hours. The third phase also required three animals, which are divided into three groups of one animal each. Various high doses of the extract $(3000 \mathrm{mg} / \mathrm{kg}, 4000 \mathrm{mg} / \mathrm{kg}$ and $5000 \mathrm{mg} / \mathrm{kg}$ as the highest) were administered to the different animals. For all the phases studied, observation was conducted 1 hour after administration and then 10 minutes every 2 hours for 24 hours. Behavioral toxicity signs and mortality were noted. 


\section{Collection of blood sample}

The experimental animals were humanely sacrificed after 28 days, and plasma was collected in EDTA tubes for haematological studies. Serum was collected in plain tubes for lipid profile estimation.

\section{Body weight/Relative organ weight determination}

The percentage change in the body weight of the experimental animals was calculated as:

$\{$ Final body weight-initial body weight $\}$ / final body weight $\} \times 100$

Similarly, after sacrificing the animals, the kidney, liver, heart and spleen were promptly excised and weighed using a top loading balance and their relative organ weight calculated thus:

Relative organ weight $=$ organ weight $[\mathrm{g}] /$ body weight $[\mathrm{g}]$

\section{Assay of lipid profile}

Component lipids such as cholesterol, high-density lipoprotein-cholesterol (HDL-C), Triacylglycerol, very low-density lipoprotein (VLDL-C) and low-density lipoprotein (LDL-C) cholesterol concentrations were estimated using standard commercial test kits obtained from RANDOX, Diamond Road Crumlin, Co. Antrim, United Kingdom. LDL-cholesterol was estimated from the values of total cholesterol, triacylglycerol and HDL-cholesterol using the method described by (Friedewald et al., 1972):

$$
\begin{gathered}
\text { LDL-cholesterol }=\text { total cholesterol }- \text { triacylglyc- } \\
\text { erol } / 5 \text { - HDL-cholesterol }
\end{gathered}
$$

The VLDL-cholesterol concentration of serum was determined by calculation from the triglyceride concentration according to the method described by Friedewald et al. (1972):

$$
\text { VLDL-cholesterol }=\text { triacylglycerol } / 5[\mathrm{mg} / \mathrm{dl}]
$$

\section{Statistical analysis}

The results were expressed as mean $\pm \mathrm{SD}$. Data were analyzed using one-way analysis of variance (ANOVA) using SPSS version 20.0. Differences between means were considered to be significant at $(p<0.05)$ using the post hoc test (Least Square Difference).

\section{RESULTS AND DISCUSSION}

The proximate composition of the leaves of J. carnea (Table 1) shows that the leaves have a high carbohydrate content $(45.95 \pm 0.06)$, protein $(19.56 \pm 0.19)$ and moisture content $(18.03 \pm 0.14)$, a moderate concentration of fiber (12.02 \pm 0.14$)$ and a low concentration of ash $(4.37 \pm 0.22)$ and fat $(1.08 \pm 0.07)$. The high carbohydrate content in the leaves indicates that the leaves could be potential sources for energy requirement, which supplies energy to cells such as the brain, muscles and blood (Ejelonu et al., 2011). The high protein content $(19.56 \%)$ in the leaves could enhance growth, replacement of damaged tissues and also formation of enzymes, hormones and antibodies (Emebu and Anyika, 2011). The moisture content of the leaves shows that the plant is a good source of water from vegetables for the cells of the body (Okeke et al., 2008). The ash content (4.37\%) in the leaves indicates that they contain an appreciable amount of mineral elements. The leaves of $J$. carnea have a low fat content $(1.08 \%)$ and this can be compared to Ficus capensis, which contains $1.83 \%$ fat. The low fat content of leafy vegetables naturally would lower fat intake (Achi et al., 2017). The moderate fiber content of this vegetable would help manage constipation problems, and also protect against cancer and digestive disorders (Selvendran, 1984). The results of the proximate

Table 1. Proximate and some vitamin composition of Justicia carnea leaves

\begin{tabular}{lr}
\hline \multicolumn{1}{c}{ Components } & Value, $\%$ \\
\hline Protein & $19.56 \pm 0.19$ \\
Ash & $4.37 \pm 0.22$ \\
Fat & $1.07 \pm 0.07$ \\
Crude fiber & $12.02 \pm 0.14$ \\
Moisture & $18.03 \pm 0.14$ \\
Carbohydrate & $45.95 \pm 0.06$ \\
\hline
\end{tabular}

Results are expressed as mean \pm standard deviation (SD) of three replicates. 
Onyeabo, Ch., Achi, N. K., Ekeleme-Egedigwe, Ch. A., Ebere, Ch. U., Okoro, Ch. K. (2017). Haematological and biochemical studies on Justicia carnea leaves extract in phenylhydrazine induced-anemia in albino rats. Acta Sci. Pol. Technol. Aliment., 16(2), $217-230$. http://dx.doi.org/10.17306/J.AFS.2017.0492

Table 2. Some vitamin composition of Justicia carnea leaves

\begin{tabular}{lc}
\hline \multicolumn{1}{c}{ Vitamin } & Concentration \\
\hline Vitamin A, $\mu \mathrm{g}$ & $31.65 \pm 0.64$ \\
Vitamin C, $\mathrm{mg} / 100 \mathrm{~g}$ & $6.40 \pm 0.23$ \\
Vitamin E, $\mathrm{mg} / 100 \mathrm{~g}$ & $1.53 \pm 0.04$ \\
\hline
\end{tabular}

Results are expressed as mean \pm standard deviation (SD) of three replicates.

composition show that the leaves of this plant constitute rich sources of food nutrients. Vitamins A (31.65 $\mu \mathrm{g}), \mathrm{C}(6.40 \mathrm{mg} / 100 \mathrm{~g})$ and $\mathrm{E}(1.53 \mathrm{mg} / 100 \mathrm{~g})$ estimated in the leaves of this vegetable were considered to identify antioxidant vitamins in the leaves. The species of Justicia have been reported to be rich sources of both vitamins and minerals (Faiza et al., 2013). The high content of Vitamin A in this leafy vegetable could be attributed to the reddish colour released when the leaves are boiled or soaked in hot water. The presence of antioxidant vitamins (A, C and E) in the leaves of $J$. carnea could contribute to the decrease in oxidative stress caused by the phenylhydrazine drug by scavenging free radicals. These results are in agreement with (Orjiakor, 2014), suggesting that these leaves could play a role in curbing oxidative stress caused by phenylhydrazine invitro. Vitamin $\mathrm{C}$ also contributes to the bioavailability of iron in the body (Staubli Asobayire, 2000). Table 3 shows both the qualitative and quantitative phytochemical composition of $J$. carnea leaves. The leaves showed the presence of saponins, alkaloids and terpenoids in high quantities, while steroids, flavonoids and phenols appeared in moderate amounts and tannins in trace amounts. Phytochemicals, mainly alkaloids, lignans, flavonoids, and terpenoids (iridoids, diterpenoids, and triterpenoids), have been reported to be found in many species of Justicia (Corrêa and Alcântara, 2012). Flavonoids are the largest group of plant phenols and provide a great deal of flavor and colour to fruits and vegetables (Tanwar and Modgil, 2012). This may be attributed to the purplish red colour released despite its green leaves when boiled. Flavonoids have been reported to have antiprotozoal, antibacterial and antiviral actions (Sridhar et al., 2014). Flavonoids also possess antioxidant capacity because they neutralize free radicals, which
Table 3. Some phytochemical composition of Justicia carnea leaves

\begin{tabular}{lcc}
\hline Components & Qualitative tests & Quantitative value, \% \\
\hline Steroids & ++ & $4.18 \pm 0.25$ \\
Saponins & +++ & $17.02 \pm 0.07$ \\
Alkaloids & +++ & $12.21 \pm 0.04$ \\
Flavonoids & ++ & $4.90 \pm 0.03$ \\
Tannins & + & $0.01 \pm 0.00$ \\
Phenols & ++ & $5.15 \pm 0.00$ \\
Terpenoids & ++ & $15.78 \pm 0.05$ \\
\hline
\end{tabular}

+++- present in a high amount

++- a moderately high amount.

+- present in a trace amount.

-- absent.

Results are expressed as mean \pm standard deviation (SD) of three replicates.

attack most cells in the body, thereby counteracting diseases such as cancer, heart disease and even aging (Ekanayake et al., 2000). The presence of alkaloids in this leafy vegetable indicates its use for medicinal purposes such as analgesic, anti-spasmodic, anti-cancer and bactericidal effects (Saxena et al., 2013; Stary, 1998). Alkaloids are known for their toxicity, but not all alkaloids are toxic, some of them are considered to be anti-nutrients due to their action on the nervous system (Gemede and Ratta, 2014). Certain mammalian enzymic activities such as phosphodiesterase, which prolongs the action of cAMP, are inhibited by alkaloids (Ekeanyanwu et al., 2010). Saponins are phytochemical with structural diversity and biological activities (Elekofehinti, 2015) reported to possess antidiabetic (Lee et al., 2011), antioxidant (Elekofehinti et al., 2012), antiobesity (Han et al., 2002), antimicrobial (Achi et al., 2017) and anti-hyperlipidemic roles (Tammi et al., 2000). Saponins were found in the leaves of $J$. carnea in copious amounts and this could serve as a natural source of the aforementioned pharmacological actions. Saponins and alkaloids have been reported to possess anti-anemic potential (Falcone et al., 1997). With respect to their phenol component, the antioxidant potential of leaves could be attributed to its phenolic components and therefore be beneficial 
to health (Aberoumand, 2012). In addition to these, phenolics can also act as anti-cancer, anti-inflammatory, anti-allergic, estrogenic and immunomodulatory agents (Tawaha et al., 2007). Steroids were found to be present in $J$. carnea leaves and could be beneficial for humans because their presence in the form of phytosterols could decrease the cholesterol concentrations in the blood (Sadava et al., 2011). These phytosterols are also known mainly for their effect on lipid metabolism (Bartnikowska., 2009). Most of the anti-nutrients in the leaves (steroids, tannins and saponins) could be reduced by various processing methods such as boiling, soaking and roasting (Soetan, 2008).

The acute toxicity test $\left(\mathrm{LD}_{50}\right)$ of the ethanol leaf extract of $J$. carnea leaves on mice (Table 4) showed that no deaths were recorded amongs the mice, even at $5000 \mathrm{mg} / \mathrm{kg}$, signifying no symptoms of toxicity during the investigation and therefore the leaves could be safe for both human and animal consumption. The relative organ weight of all experimental groups is shown in Table 5. There was no significant $(p<0.05)$ difference in the relative heart, liver and kidney weight for all groups relative to the non-anemic and anemic control. This indicates that the leaves of $J$. carnea were not toxic for the organs at the doses administered. The relative spleen weight was significantly $(p<0.05)$ greater in the anemic control (group 2) when compared to the non-anemic group and treated groups. This effect is mainly the consequence of the metabolism of
Table 4. Phase I, II and III of the acute toxicity $\left(\mathrm{LD}_{50}\right)$ test of ethanol leaf extract of Justicia carnea

\begin{tabular}{lcc}
\hline & Dosage, $\mathrm{mg} / \mathrm{kg}$ body weight & Mortality \\
\hline Phase I & 100 & $0 / 1$ \\
Group 1 & 300 & $0 / 1$ \\
Group 2 & 500 & $0 / 1$ \\
Group 3 & 800 & $0 / 1$ \\
Group 4 & & \\
Phase II & 1000 & $0 / 1$ \\
Group 1 & 1500 & $0 / 1$ \\
Group 2 & 2000 & $0 / 1$ \\
Group 3 & & \\
Phase III & 3000 & $0 / 1$ \\
Group 1 & 4000 & $0 / 1$ \\
Group 2 & 5000 & $0 / 1$ \\
Group 3 & & \\
\hline
\end{tabular}

0/1 - no death recorded.

phenylhydrazine, as was been suggested earlier. The spleen serves to cleanse the body of damaged old particles transported by the blood (Jakubovský et al., 1990). This suggests that an increase in the relative spleen weight might be attributed to the spleen

Table 5. Relative organ weight of phenylhydrazine-induced anemic rats administered with extracts of Justicia carnea leaves

\begin{tabular}{ccccc}
\hline Groups & Heart & Liver & Kidney & Spleen \\
\hline 1 & $3.7 \times 10^{-3 \mathrm{a}} \pm 6.0 \times 10^{-4}$ & $3.8 \times 10^{-2 \mathrm{a}} \pm 3.0 \times 10^{-3}$ & $5.6 \times 10^{-3 \mathrm{a}} \pm 3.4 \times 10^{-3}$ & $3.6 \times 10^{-3 \mathrm{a}} \pm 8.0 \times 10^{-4}$ \\
2 & $3.5 \times 10^{-3 \mathrm{a}} \pm 4.0 \times 10^{-4}$ & $3.5 \times 10^{-2 \mathrm{a}} \pm 3.0 \times 10^{-3}$ & $7.2 \times 10^{-3 \mathrm{a}} \pm 1.4 \times 10^{-3}$ & $5.8 \times 10^{-3 \mathrm{~b}} \pm 7.0 \times 10^{-4}$ \\
3 & $3.6 \times 10^{-3 \mathrm{a}} \pm 8.0 \times 10^{-4}$ & $3.9 \times 10^{-2 \mathrm{a}} \pm 5.8 \times 10^{-3}$ & $8.1 \times 10^{-3 \mathrm{a}} \pm 1.7 \times 10^{-3}$ & $4.9 \times 10^{-3 \mathrm{a}} \pm 1.0 \times 10^{-4}$ \\
4 & $3.4 \times 10^{-3 \mathrm{a}} \pm 5.0 \times 10^{-4}$ & $3.9 \times 10^{-2 \mathrm{a}} \pm 1.2 \times 10^{-3}$ & $8.3 \times 10^{-3 \mathrm{a}} \pm 1.3 \times 10^{-3}$ & $3.3 \times 10^{-3 \mathrm{a}} \pm 5.0 \times 10^{-4}$ \\
5 & $3.3 \times 10^{-3 \mathrm{a}} \pm 5.0 \times 10^{-4}$ & $3.8 \times 10^{-2 \mathrm{a}} \pm 1.4 \times 10^{-3}$ & $6.7 \times 10^{-3 \mathrm{a}} \pm 1.2 \times 10^{-3}$ & $3.6 \times 10^{-3 \mathrm{a}} \pm 7.0 \times 10^{-4}$ \\
\hline
\end{tabular}

Values are means $\pm \mathrm{SD}$.

Means with different superscript letters in the columns are significantly different $(p<0.05)$.

Groups: 1 - non-anemic control, 2 - anemic control, 3 - anemic + treated $(500 \mathrm{mg} / \mathrm{kg}), 4$ - anemic

+ treated $(1000 \mathrm{mg} / \mathrm{kg}), 5-\mathrm{DMSO}$ control. 
Onyeabo, Ch., Achi, N. K., Ekeleme-Egedigwe, Ch. A., Ebere, Ch. U., Okoro, Ch. K. (2017). Haematological and biochemical studies on Justicia carnea leaves extract in phenylhydrazine induced-anemia in albino rats. Acta Sci. Pol. Technol. Aliment., 16(2), $217-230$. http://dx.doi.org/10.17306/J.AFS.2017.0492

Table 6. Body weight and percentage weight gain of phenylhydrazine-induced anemic rats administered with extracts of Justicia carnea leaves

\begin{tabular}{lccccc}
\hline \multicolumn{1}{c}{ Groups } & 1 & 2 & 3 & 4 & 5 \\
\hline Initial weight, g & $163.10 \pm 7.19^{\mathrm{a}}$ & $164.00 \pm 2.53^{\mathrm{a}}$ & $168.70 \pm 3.41^{\mathrm{a}}$ & $163.93 \pm 3.76^{\mathrm{a}}$ & $167.62 \pm 4.77^{\mathrm{a}}$ \\
Final weight, g & $201.85 \pm 15.99^{\mathrm{b}}$ & $180.50 \pm 7.48^{\mathrm{b}}$ & $198.05 \pm 15.07^{\mathrm{b}}$ & $186.05 \pm 7.49^{\mathrm{b}}$ & $201.50 \pm 24.24^{\mathrm{b}}$ \\
Percentage change, $\%$ & 19.19 & 9.14 & 14.82 & 11.89 & 11.85 \\
\hline
\end{tabular}

Groups: 1 - non-anemic control, 2 - anemic control, 3 - anemic + treated $(500 \mathrm{mg} / \mathrm{kg}), 4-$ anemic + treated $(1000 \mathrm{mg} / \mathrm{kg}), 5-$ DMSO control.

Values are expressed as means \pm SD.

Means with a different superscript for each of the groups in the rows are significantly different $(p<0.05)$.

fighting foreign particles due to the anemic condition of the rats in group 2. This is also consistent with authors who suggested that the rate of erythropoiesis and 2'5'-A polymerase activity increases after a dose of phenylhydrazine (Orlic et al., 1982). The percentage change in the body weight of animals administered ethanol extract of $J$. carnea leaves is shown in Table 6 . There were significant $(p<0.05)$ increases in the body weight of all groups of animals studied in respect to the initial and final body weight changes. Though there was an increase in the body weight of the anemic control (group 2), it had the lowest percentage change in body weight (9.14). This could be attributed to the reduced action of enzymes involved in digesting starch in the anemic rats, while the higher values in percentage body weight (groups 1, 3, 4 \& 5) could be attributed to the non-toxic nature of the extracts of the plant, which corresponds to the results of the relative organ weight of the animals.

The pictorial presentation of Justicia carnea leaves used for this study is shown in Figure 1. Figure 2 shows that after 48 hours of induction of anemia, there was a significant $(p<0.05)$ decrease in Packed Cell Volume (PCV) levels in the phenylhydrazine induced groups $(2,3 \& 4)$ relative to the non-anemic control (group 1). The reduction in PCV values by more than $50 \%$ of the baseline values in all rats on the $2^{\text {nd }}$ day after phenylhydrazine administration is an indication that the animals were anemic. After 14 days of treatment with $J$. carnea leaves, there was a significant $(p<0.05)$ decrease in PCV values in group 2 (anemic control) relative to group 1(non-anemic control). Groups 3 and 4 showed no significant $(p<0.05)$ difference relative to group 1 ,

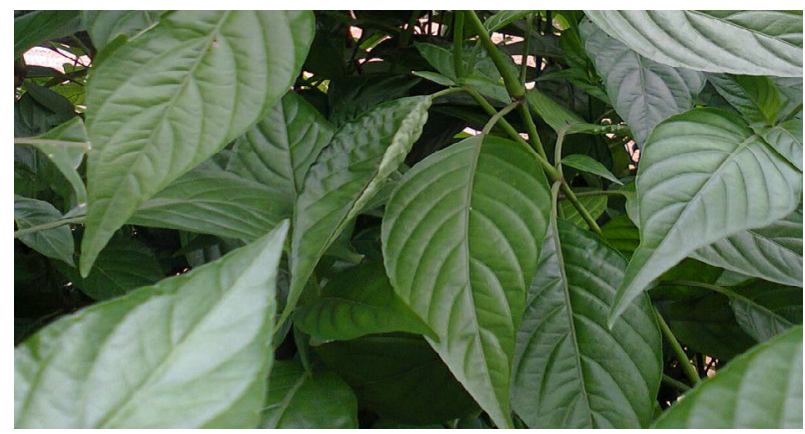

Fig. 1. Leaves of Justicea carnea

while a significant $(p<0.05)$ increase in PCV values was observed in groups $3 \& 4$ when compared to group 2 (anemic control). This indicates that there was a gradual reversal of anemic condition when extracts of $J$. carnea were administered on the $14^{\text {th }}$ day. After 28 days of treatment, there was a significant $(p<0.05)$ increase in the PCV count in groups 3 and 4 relative to group 1 (non-anemic control). A significant $(p<0.05)$ increase in PCV count was also recorded in all groups relative to the group 2 (Anemic control). This indicates that extracts of $J$. carnea increased RBC count and PCV and therefore could be said to have reversed the anemic condition after 28 days. According to Berger (2007), animals were considered anemic when decreases in $\mathrm{Hb}$ level, RBC count, PCV and impaired erythrocyte deformability were observed when phenylhydrazine was administered to the animals. The increase in PCV could be a result of the body's response to low PCV level resulting in the production of blood cells in order not to deprive the animal of oxygen in circulation. Phytochemicals and the antioxidant vitamins in the 


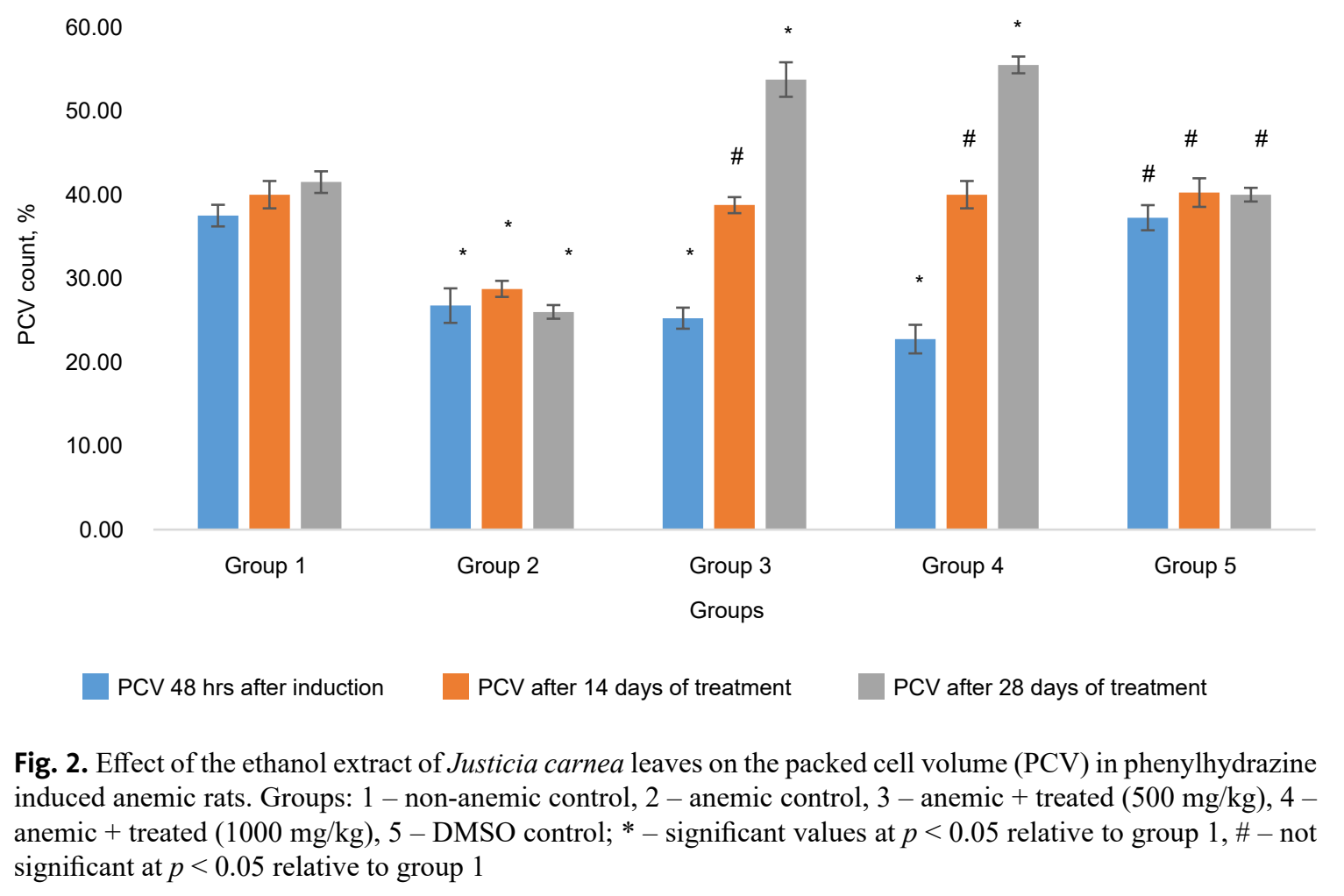

leaves of the plant could be responsible for this antianemic effect by reversing the effects of phenylhydrazine drug. Moreover, there was a significant $(p<0.05)$ increase in the RBC count (Fig. 3) of rats in groups 3 $\& 4$ relative to the non-treated anemic rats (group 2). Oxidative damage to red blood cells by forming reactive oxygen species when phenylhydrazine drug was induced has been reported by researchers (Clemens et al., 1984). Therefore, the increase in RBC count could be attributed to the rich milieu of phytochemicals (saponins, flavonoids and alkaloids) and antioxidants in the plant extract and thus could reverse the damaging effects of phenylhydrazine anemia. These results agree with reports on extracts of Tectona grandis (Diallo et al., 2008) and extracts of M. indica, A. hybridus and T. occidentalis (Ogbe et al., 2010), which increased the concentration of haemoglobin and red blood cells after induction with phenylhydrazine (Diallo et al., 2008). A significant decrease $(p<0.05)$ in haemoglobin $(\mathrm{Hb})$ concentrations was observed in groups 2 and 3 relative to group 1 (non anemic control; 4). A significant increase $(p<0.05)$ in $\mathrm{Hb}$ concentrations was observed in groups 1,3 , and 4 relative to group 2 . The anemic rats that were administered extracts at $500 \mathrm{mg} / \mathrm{kg}$ and $1000 \mathrm{mg} / \mathrm{kg}$ of the extract showed an increase in their $\mathrm{Hb}$ concentration, possibly indicating that from the dosages, the potency of the extract as a blood booster was expressed in the rats as shown in Figure 4. This suggests that the animals recovered from anemia when treated with the plant extract, which might induce the haemopoietic pathway. This result confirms scientific reports where extracts of $M$. indica, A. hybridus and $T$. occidentalis increased $\mathrm{Hb}$ concentration in rats (Ogbe et al., 2010). Findings also show a significant $(p<0.05)$ increase in the WBC count (Fig. 5) of animals in groups 3 and 4 relative to group 2. The increase in the WBC count of group $3 \& 4$ could be a result of the extract reversal of the anemic condition after induction of phenylhydrazine drug. "The animal's immune system may assume that the cause of anemia could be a result of infection or disease and hence increase the production of white blood cells to fight such infections" (Okonkwo et al., 2015). WBC counts increase rapidly following a foreign attack on the system by pathogens and the normal physiologic response of the system will be to boost the body's defense mechanisms (Eyong et al., 2004). 


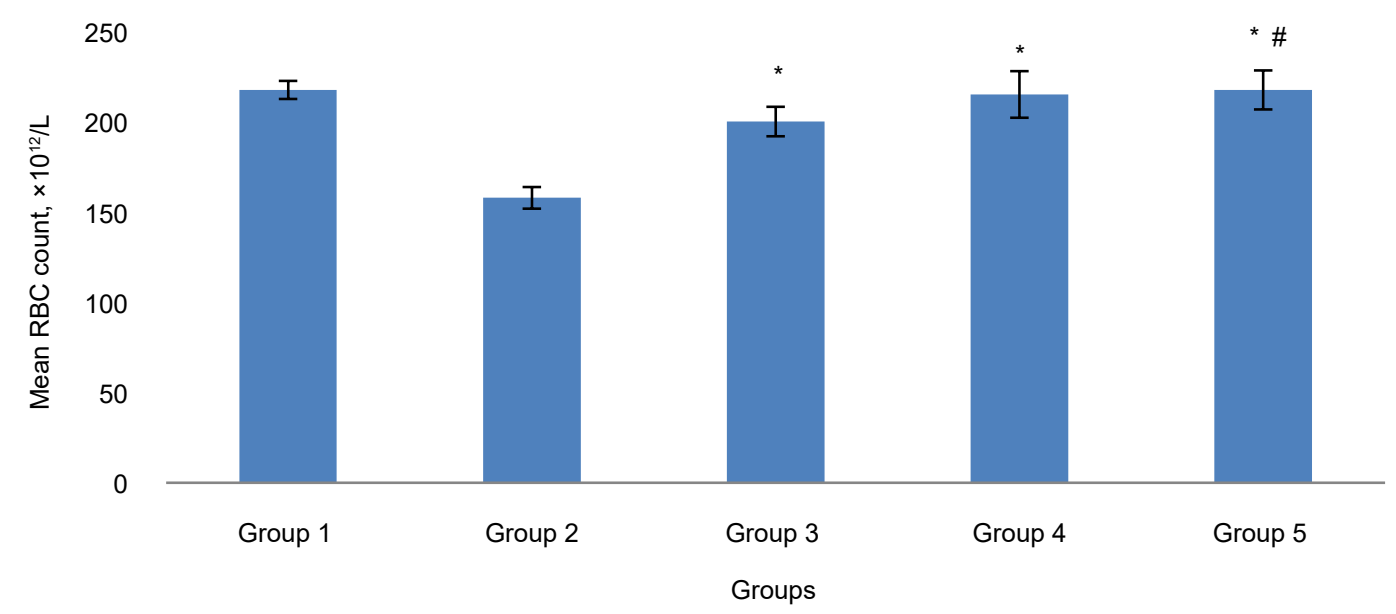

Fig. 3. Effect of the ethanol extract of Justicia carnea leaves on the red blood cell count (RBC) in phenylhydrazine induced anemic rats. Groups: 1 - non-anemic control, 2 - anemic control, 3 - anemic + treated $(500 \mathrm{mg} / \mathrm{kg}), 4-$ anemic + treated $(1000 \mathrm{mg} / \mathrm{kg}), 5-$ DMSO control; * - significant values at $p<0.05$ relative to group $2, \#-$ not significant value at $p<0.05$ relative to group 1

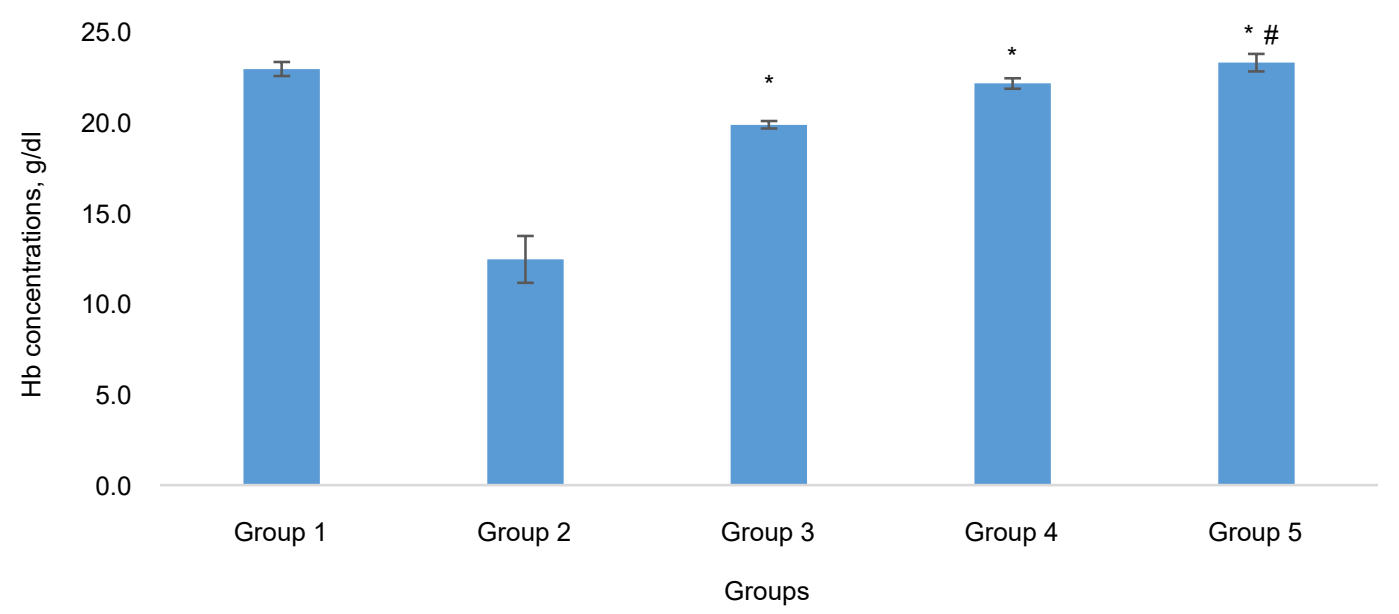

Fig. 4. Effect of the ethanol extract of Justicia carnea leaves on the haemoglobin concentration in phenylhydrazine induced rats. Groups: 1 - non-anemic control, 2 - anemic control, 3 - anemic + treated $(500 \mathrm{mg} / \mathrm{kg}), 4-$ anemic + treated $(1000 \mathrm{mg} / \mathrm{kg}), 5-$ DMSO control; $*$ - significant values at $p<0.05$ relative to group $2, \#-$ not significant at $p<0.05$ relative to group 1

The results for the lipid profile are shown in Table 7. There was no significant $(p<0.05)$ difference in cholesterol concentrations in the animals treated with $500 \mathrm{mg} / \mathrm{kg}$ (group 3) of Justicia carnea leaves relative to the non-anemic control (group 1), while a significant $(p<0.05)$ decrease in cholesterol concentrations treated with $1000 \mathrm{mg} / \mathrm{kg}$ (group 4) of J. carnea leaves compared to the non-anemic control. This suggests that at $1000 \mathrm{mg} / \mathrm{kg}$ of extract administration was significant in modulating cholesterol concentrations. The decrease in serum cholesterol could be beneficial to individuals with hypercholesterolemia, thereby reducing the risk of cardiovascular diseases and other diseases (Ijeh and Egedigwe, 2010). This decrease 


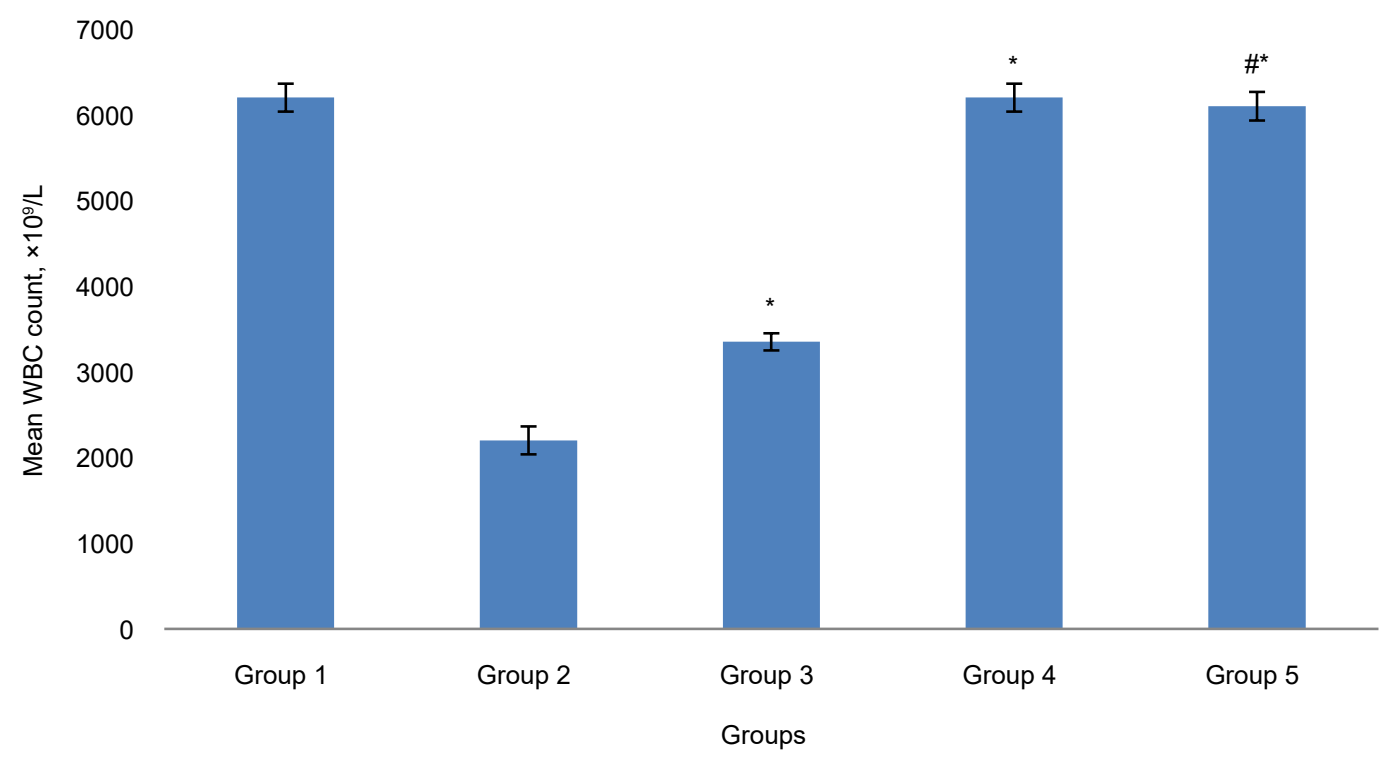

Fig. 5. Effect of the ethanol extract of Justicia carnea leaves on the white blood cell count (WBC) in phenylhydrazine induced anemic rats. Groups: 1 - non-anemic control, 2 - anemic control, 3 - anemic + treated $(500 \mathrm{mg} / \mathrm{kg}), 4-$ anemic + treated $(1000 \mathrm{mg} / \mathrm{kg}), 5-$ DMSO control; ${ }^{*}$ - significant values at $p<0.05$ relative to group 2 , \# - not significant at $p<0.05$ relative to group 1

Table 7. Lipid profile concentrations in phenylhydrazine-induced anemic rats administered with extracts of Justicia carnea leaves

\begin{tabular}{cccccc}
\hline Groups & $\begin{array}{c}\text { Total cholesterol } \\
\mathrm{mmol} / \mathrm{L}\end{array}$ & $\begin{array}{c}\text { HDL-C } \\
\mathrm{mmol} / \mathrm{L}\end{array}$ & $\begin{array}{c}\text { Triacylglycerol } \\
\text { concentration } \\
\text { mmol/L }\end{array}$ & $\begin{array}{c}\text { LDL-C } \\
\mathrm{mmol} / \mathrm{L}\end{array}$ & $\begin{array}{c}\text { VLDL-C } \\
\mathrm{mmol} / \mathrm{L}\end{array}$ \\
\hline 1 & $3.10 \pm 0.18^{\mathrm{a}}$ & $1.23 \pm 0.02^{\mathrm{a}}$ & $1.36 \pm 0.01^{\mathrm{a}}$ & $1.54 \pm 0.21^{\mathrm{a}}$ & $0.27 \pm 0.03^{\mathrm{a}}$ \\
2 & $3.15 \pm 0.13^{\mathrm{a}}$ & $1.25 \pm 0.03^{\mathrm{a}}$ & $1.31 \pm 0.01^{\mathrm{a}}$ & $1.67 \pm 0.10^{\mathrm{a}}$ & $0.26 \pm 0.01^{\mathrm{a}}$ \\
3 & $3.12 \pm 0.05^{\mathrm{a}}$ & $1.30 \pm 0.02^{\mathrm{b}}$ & $1.25 \pm 0.02^{\mathrm{b}}$ & $1.24 \pm 0.15^{\mathrm{b}}$ & $0.25 \pm 0.01^{\mathrm{a}}$ \\
4 & $2.67 \pm 0.15^{\mathrm{b}}$ & $1.38 \pm 0.01^{\mathrm{b}}$ & $1.22 \pm 0.01^{\mathrm{b}}$ & $1.18 \pm 0.18^{\mathrm{b}}$ & $0.25 \pm 0.02^{\mathrm{a}}$ \\
5 & $2.90 \pm 0.13^{\mathrm{a}}$ & $1.25 \pm 0.01^{\mathrm{a}}$ & $1.33 \pm 0.03^{\mathrm{a}}$ & $1.40 \pm 0.06^{\mathrm{a}}$ & $0.27 \pm 0.02^{\mathrm{a}}$ \\
\hline
\end{tabular}

Values are expressed as mean $\pm \mathrm{SD}$. Means with different superscript in each column are significantly different at $p<0.05$ (cholesterol and LDL-cholesterol), $p<0.001$ (HDL-cholesterol, triacylglyceol and VLDL-C). Groups: 1 - non-anemic control, 2 - anemic control, 3 - anemic + treated $(500 \mathrm{mg} / \mathrm{kg}), 4-$ anemic + treated $(1000 \mathrm{mg} / \mathrm{kg}), 5-\mathrm{DMSO}$ control.

in cholesterol concentrations might be attributed to the phytochemicals present such as saponins. Saponins have been reported to reduce the uptake of cholesterol in the gut through intra-lumenal physicochemical interaction (Price et al., 1987) and thereby help reduce cholesterol. High Density Lipoprotein (HDL)-Cholesterol concentrations showed a significant $(p<0.001)$ increase in the groups treated with extracts 
(3 and 4) relative to both the anemic and non-anemic groups (1 and 2). HDLs remove cholesterol from plasma and from cells of nonhepatic tissues, returning it to the liver (Moran et al., 2006). HDL inhibits the oxidation of LDL by transition metal ions, but also prevents 12-lipooxygenase-mediated formation of lipid hydroperoxides (Nofer et al., 2002). Triacylglycerol concentrations as shown in the groups treated ( 3 and 4$)$ showed significant $(p<0.001)$ decreases relative to both the non-anemic and anemic control groups (groups 1 and 2). The decrease observed in triacylglycerol concentrations in the extract-treated group could be attributed to the rich milieu of phytochemicals found in the leaves. LDL-cholesterol concentrations in the extract-treated groups showed significant $(p<0.05)$ decreases relative to the nonanemic control group. High levels of LDL, which are tagged "bad cholesterol", increase the chances of developing atherosclerosis (Moran et al., 2006). Increased LDL concentrations are associated with atherosclerosis, heart attack, stroke and cardiovascular diseases (Bordia and Verma, 1998; Cromwell and Otvos, 2004). VLDL cholesterol concentrations showed no $(p<0.001)$ significant differences in the extract-treated groups (groups 3 and 4 ) relative to the non-anemic (group 1) and anemic control (group 2) groups though slight decreases in values was observed in groups 3 and 4.

\section{CONCLUSION}

The proximate values and presence of phytochemicals in the leaves were very reasonable, which suggests that the leaves of this plant can make valuable contributions to improved nutrition and well-being. This study shows that $J$. carnea extracts possess antianemic potential, lending credence to the use of these plant extracts in folk medicine for the management of hemolytic anemia. The observations from this study revealed that leaves of $J$. carnea not only possess antianemic properties as reportedly used by traditional healers, but have hypolipidaemic potential, which could be beneficial to individuals predisposed to cardiovascular diseases. Further studies are warranted to determine the bioactive component present in $J$. carnea leaves that could be responsible for both anti-anemic and hypolipidaemic effects.

\section{REFERENCES}

Aberoumand, A. (2012). Screening of phytochemical compounds and toxic proteinaceous protease inhibitor in some lesser-known food based plants and their effects and potential applications in food. Int. J. Food Sci. Nutr. Eng., 2(3), 16-20. http://dx.doi.org/10.5923/j. food.20120203.01

Achi, N. K., Onyeabo, C., Ekeleme-Egedigwe, C. A., Onyeanula, J. C. (2017). Phytochemical, proximate analysis, vitamin and mineral composition of aqueous extract of Ficus capensis leaves in South Eastern Nigeria. J. Appl. Pharm. Sci., 7(3), 117-122. http://dx.doi. org/10.7324/JAPS.2017.70319

AOAC (1990). Official methods of analysis (pp. 69-88). $15^{\text {th }}$ ed. Washington, D.C.: Association of Official Analytical Chemist.

Ashour, T. H. (2014). Hematinic and anti-anemic effects of thymoquinone against phenylhydrazine induced hemolytic anemia in rats. Res. J. Med. Sci., 8(2), 67-72.

Badami, S., Aneesh, R., Sankar, S., Sathishkumar, M. N., Suresh, B., Rajan S. (2003). Antifertility activity of Derris brevipes variety coriacea. J. Ethnopharm., 84, 99-104. PMID: 12499083.

Bartnikowska, E. (2009). Biological activities of phytosterols with particular attention to their effects on lipid metabolism. Pol. J. Food Nutr Sci., 59(2), 105-112. Retrieved from http://journal.pan.olsztyn.pl

Berger, J. (2007). Review: Phenylhydrazine haematotoxicity. J. Appl. Biomed., 5, 125-130.

Bordia, A., Verma, S. K. (1998). Effect of Celastrus paniculatus wild oil (Bravobol) on blood lipids in patients of coronary. Antiseptic, 95(4), 112.

Bull, B. S., Breton-Gorius, J. (1995). Morphology of the erythron. Williams hematology (pp. 349-352). New York, NY: McGraw-Hill.

Chattopadhyay, R. R., Bandyopadhyay, M. (2005). Effect of Azadirachta indica leaf extract on serum lipid profile changes in normal and streptozotocin induced diabetic rats. Afr. J. Biomed. Res., 8, 101-104. Retrieved from http://www.bioline.org.br/md

Corrêa, G. M., de C. Alcântara, A. F. (2012) Chemical constituents and biological activities of species of Justicia A Review. Braz. J. Pharmacogn., 22(1), 220-238. http:// dx.doi.org/10.1590/S0102-695X2011005000196

Clemens, M. R., Remmer, H., Waller, H. D. (1984). Phenylhydrazine-induced lipid peroxidation of red blood cells in vitro and in vivo: Monitoring by the production of volatile hydrocarbons. Biochem. Pharmacol., 33, 17151718. https://doi.org/10.1016/0006-2952(84)90338-1 

on Justicia carnea leaves extract in phenylhydrazine induced-anemia in albino rats. Acta Sci. Pol. Technol. Aliment., 16(2), $217-230$. http://dx.doi.org/10.17306/J.AFS.2017.0492

Cromwell, W. C., Otvos, J. D. (2004). Low density lipoprotein particles number and risk for cardiovascular disease. Curr. Atheroscl., Reports, 6, 381-387. http:// dx.doi.org/10.1007/s11883-004-0050-5

Diallo, A., Gbeassor, M., Vovor, A., Eklu-Gadegbeku, K., Aklikokou, K. Agbonon, A. (2008). Effect of Tectona grandis on phenylhydrazine induced anemia in rats. Fitoterapia, 79, 332-336. http://dx.doi.org/10.1016/j. fitote.2008.02.005

Durkee, L. H. (1986). Family 200 Acanthaceae. In: W. Burger (Ed.), Flora Costaricensis (pp. 1-87). Fieldiana Botany n.s., 18.

Ejelonu, B. C., Lasisi, A. A., Olaremu, A. G., Ejelonu, O. C. (2011). The chemical constituents of calabash (Crescentia cujete). Afr. J. Biotechn., 10(84), 19631-19636. http://dx.doi.org/10.5897/AJB11.1518

Ekanayake, S., Jansz, E. R., Nair, B. M. (2000). Literature review of an underutilized legume: Canavalia gladiata L. Plant Foods Hum. Nutr. 55(4), 305-321. PMID: 11086874.

Ekeanyanwu, R. C., Njoku, O. U., Ononogbu, I. C. (2010). The phytochemical composition and some biochemical effects of Nigerian tigernut (Cyperus esculentus L.) tuber. Pak. J. Nutr., 9(7), 709-715. http://dx.doi. org/10.3923/pjn.2010.709.715

Elekofehinti, O. O. (2015). Saponins: Anti-diabetic principles from medicinal plants - A review. Pathophysiology, 22, 95-103. http://dx.doi.org/10.1016/j. pathophys.2015.02.001

Elekofehinti, O. O., Kamdem, J. P., Kade, I. J., Adanlawo, I. G. Rocha, J. B. T. (2012). Saponins from Solanum anguivi Lam. fruit exhibit in vitro and in vivo antioxidant activities in alloxan-induced oxidative stress. Asian J. Pharm. Clin. Res., 6, 249-254. http://www.ajpcr.com/ Vol6Suppl2/1760.pdf

Emebu, P. K., Anyika, J. U. (2011). Proximate and mineral composition of Kale (Brassica oleracea) grown in Delta State, Nigeria. Pak. J. Nutr., 10(2), 190-194. http:// dx.doi.org/10.3923/pjn.2011.190.194

Eyong, E. U., Umoh, I. B., Ebong, P. E., Eteng, M. U. Antai, A. B., Akoa, A. O. (2004). Heamotoxic effects following ingestion of Nigerian crude oil and crude oil polluted shellfish by rats. Nig. J. Physiol. Sci., 19(1-2), 1-6.

Faiza, R., Waqas, K. K., Adeel, M., Muhammad, G. (2013). Detection of bioactive fractions of Justicia adhatoda leaves. Can. J. Appl. Sci., 1(3), 388-398.

Falcone, A., Musto, P., Rasario, P., Rosella, M. (1997). Compounds and methods for treatment of chemotherapy-induced anemia. Eur. J. Haematol., 58, 34-319.
Fasuyi, A. O. (2006). Nutritional potentials of some tropical vegetable leaf meals. Chemical characterization and functional properties. Afr. J. Biotechnol., 5, 49-53. http://www.academicjournals.org/AJB

Friedewald, W. T., Levy, R. I., Frederickson, D. S. (1972) Estimation of the concentration of LDL cholesterol in plasma, without the use of preparative ultra-centrifuge. Clin. Chem., 18, 499-502.

Gbenou, J. D., Tossou, R., Dansou, P., Fossou, M., Moudachirou, M. (2006). Etude des proprieties antianémiques de Justicia secunda Vahl (Acanthaceae) chez les rats de souche wistar. Pharm. Med. Trad. Afr., 14, 45-54.

Gemede, H. F., Ratta, N. (2014). Antinutritional factors in plant foods: potential health benefits and adverse effects. Int. J. Nutr. Food Sci., 3(4), 284-289. http://dx.doi. org/10.11648/j.ijnfs.20140304.18

Han, L. K., Zheng, Y. N., Xu, B. J., Okuda, H., Kimura, Y. (2002). Saponins from Platycodi radix ameliorate high fat diet-induced obesity in mice. J. Nutr., 132, 22412245. PMID:12163669.

Harborne, J. B. (1998). Phytochemical methods. A guide to modern technology of plant analysis (pp. 88-185). New York: Chapman and Hall.

Horton, H. R., Moran, L. A., Scrimgeour, K. G., Rawn, J. D. (2006). Principles of biochemistry (pp. 511-513). Pearson Prentice Hall.

Ijeh, I. I. Egedigwe, A. C. (2010). Effect of dietary incorporation of Vernonia colorata (Willd) leaves on blood lipid profile of albino rats. Int. J. Biol. Chem. Sci., 4(1), 100-106. http://ajol.info/index.php/ijbcs

Jakubovský, J., Brozman, M., Ruzicková, M., Surmíková, E., Belko, I., Líska, J., ..., Belosovic, M. (1990). Structural basis of the spleen in rats. Bratisl. Lek. Listy, 91(6), 466-478. PMID: 2393829.

Kanfer, E. J., Nicol, B. A. (1997). Haemoglobin concentration and erythrocyte sedimentation rate in primary care patients. J. R. Soc. Med., 90, 16-18. PMCID: PMC1296109.

Kumar, A., Iavarasan, R. I., Jayachandran, T., Decaraman, M., Aravindhan, P., Padmanabhan, N., Krishnan, M. R. V. (2009). Investigation on a tropical plant Syzygium cumini from Kattuppalayam, Erode District, Tamil Nadu, South India. Pak. J. Nutr., 8, 83-85. http://dx.doi. org/10.3923/pjn.2009.83.85

Lee, K. T., Jung, T. W., Lee, H. J., Kim, S. G., Shin, Y. S., Whang, W. K. (2011). The antidiabetic effect of genosenoside $\mathrm{Rb} 2$ via activation of AMPK. Arch. Pharm. Res., 34, 1201-1208. http://dx.doi.org/10.1007/ s12272-011-0719-6 
Lorke, D. (1983). A new approach to practical acute toxicity testing. Arch. Toxicol., 54, 275-287. http://dx.doi. org/10.1007/BF01234480

Mabberley, D. J. (1997). The plant-book: A portable dictionary of the vascular plants. Cambridge Univ. Press.

Medapa, S., Singh, G. R. J., Ravikumar, V. (2011). The phytochemical and antioxidant screening of Justicia wynaadensis. Afr. J. Plant Sci., 5(9), 489-492.

Moran, L. A., Horton, R. A., Scrimgeour, G., Perry M., Rawn, D. (2006). Principles of biochemistry (pp. 511513). Pearson Prentice Hall.

NIH (1978). Guide for the care and use of laboratory animals. ( $8^{\text {th }}$ ed.) Committee for the Update of the Guide for the Care. Washington DC: National Academies Press.

NRC (1985). Guide for the care and use of laboratory animals. Bethesda (MD): National Research Council, National Institute of Health.

Nofer, J. R., Kehrel, B., Fobker, M., Levkau, B., Assmann, G., von Eckardstein, A. (2002). HDL and arteriosclerosis: beyond reverse cholesterol transport. Atherosclerosis, 161, 1-16. http://dx.doi.org/10.1016/ S0021-9150(01)00651-7

Ochei, J., Kolhatkar, A. (2008). Medical laboratory sciences: Theory and practice (pp. 663-665). New York: Tata McGraw Hill. Retrieved from https://www.researchgate. net/publication/290158410_Medical_Laboratory_Science_Theory_and_Practice

Ogbe, R. J., Adoga, G. I., Abu, A. H. (2010). Antianaemic potentials of some plant extracts on phenyl hydrazineinduced anemia in rabbits. J. Med. Plants Res., 4(8), 680-684. http://dx.doi.org/10.5897/JMPR09.487

Okeke, C. U., Izundu, A. I., Uzoechinda, E. (2008). Phytochemical and proximate study of female pawpaw ( $\mathrm{Ca}$ rica papaya Linn.) Caricaceae. J. Sci. Eng. Techn., 15 (2), 8207-8216

Okonkwo, C. C., Agu, C. V., Njoku, O. U., Abonyi, U., Apeh, V., Anaduaka, E.G., ..., Odo, C. E. (2015). Hypoglycaemic and haematinic properties of ethanol leaf extract of Artocarpus heterophyllus in alloxan induced diabetic rats. Afr. J. Tradit. Comp. Altern. Med., 12(2), 144-148. http://dx.doi.org/10.4314/ajtcam.v12i2.21

Orjiakor, C. A. (2014). Studies on the phytochemical and nutritional composition of aqueous leaf extract of Justicia carnea and its effect on some biochemical parameters in anemic rats. MSc. Dissertation submitted to the Department of Biochemistry, University of Nigeria, Nsukka.

Orlic, D., Wu, J. M., Carmichael, R. D., Quaini, F., Kobylack, M., Gordon, A. S. (1982) Increased erythropoiesis and 2,5'-A polymerase activity in the marrow and spleen of phenylhydrazine-injected rats. Exp. Hematol., 10(5), 478-485. PMID: 6284534.

Oze, G., Nwanjo, H., Oze, R., Akubugwo, E., Orisakwe, E., Aka, P. (2008). Reproductive impairment associated with the ethanolic extract of Alstonia boonei (De-Wild) stem bark in male rats. Internet J. Lab. Med., 3(1), 1-10.

Price, K. R., Johnson, L. I., Fenwick, H. (1987). The chemical and biological significance of saponins in foods and feeding stuffs. Crit. Rev. Food Sci. Nutr., 26 (1), 127135. http://dx.doi.org/10.1080/10408398709527461

Radhika, J., Sathya, S., Jothi, G., Japasheba, J. L. (2013). Cardioprotective role of Justicia traquebareinsis Linn. leaf extract in isoproterenol induced myocardial infarction in albino rats. J. Appl. Pharm. Sci., 3(4), 124-128. http://dx.doi.org/10.7324/JAPS.2013.3422

Sadava, D., Hillis, D. M., Heller, H. C., Berenbaum, M. R. (2011). Life: The science of biology (pp. 105-114). San Francisco: Freeman.

Saxena, M., Saxena, J., Nema, R., Singh, D., Gupta, A. (2013). Phytochemistry of medicinal plants. J. Pharmacogn. Phytochem. Phytochem. Med. Plants, 6(1), 168-182.

Selvendran, R. R. (1984). The plant cell wall as a source of dietary fiber: chemistry and structure. Am. J. Clin. Nutr., 39, 320-337.

Soetan, K. O. (2008). Pharmacological and other beneficial effects of anti-nutritional factors in plants - A review. Afr. J. Biotechnol., 7(25), 4713-4721. http://dx.doi. org/10.5897/AJB08.024

Sridhar, N., Duggirala, S. L., Puchchakayala, G. (2014). Analyzing the phytochemical composition of Justicia neesii Ramam. J. Phytopharmac., 3(5), 348-352. Retrieved from www.phytopharmajournal.com

Stary, F. (1998). The natural guide to medicinal herb plants. London, UK: Tiger Book Int.

Staubli Asobayire, F. (2000). Development of a food fortification strategy to combat iron deficiency in the Ivory Coast. PhD Thesis, Swiss Federal Institute of Technonogy, Zurich, Switzerland.

Tammi, A., Ronnemaa, T., Gylling, H. (2000). Plant stanol ester margarine lowers serum total and low-density lipoprotein cholesterol concentrations of healthy children: the STRIP project. Special Turky Coronary Risk Factors Intervention Project. J. Pediatr., 136, 503-510.

Tanwar, B., Modgil, R. (2012). Flavonoids: Dietary occurrence and health benefits. AReview. Spatula DD, 2(1), 59 68. http://dx.doi.org/10.5455/spatula.20120328100506

Tawaha, K., Alali, F. Q., Gharaibeh, M., Mohammad, M., El-Elimat, T. (2007). Antioxidant activity and total phenolic content of selected Jordanian plant species. Food 
Onyeabo, Ch., Achi, N. K., Ekeleme-Egedigwe, Ch. A., Ebere, Ch. U., Okoro, Ch. K. (2017). Haematological and biochemical studies on Justicia carnea leaves extract in phenylhydrazine induced-anemia in albino rats. Acta Sci. Pol. Technol. Aliment., 16(2), $217-230$. http://dx.doi.org/10.17306/J.AFS.2017.0492

Chem., 104, 1372-1378. http://dx.doi.org/10.1016/j. foodchem.2007.01.064

Tchogou, A. P., Sènou, M., Dougnon, T. V., Agossadou, A., Assogba, F., Kinsiclounon, E. G., ..., Loko, F. (2016). The aqueous extract of Cocos nucifera L. (Arecaceae) effectively treat induced anemia. Experimental study on wistar rats. Int. J. Biol., 8(3), 1-10. http://dx.doi. org/10.5539/ijb.v8n3p1

WHO (2006). Guidelines on food fortification with micronutrients. Geneva: World Health Organization. Retrieved from http://www.who.int/medical_devices/initiatives/anemia_control/en/Accessed $17^{\text {th }}$ October,2016 